\title{
Pelatihan Literasi Digital Pada Sekolahrumah Salihah Yogyakarta: Animasi, Poster Digital, Video Dan Gim
}

\author{
Nur W. Rahayu ${ }^{1)}$, Nanum Sofia ${ }^{2)}$ \\ Prodi Informatika ${ }^{1)}$ Prodi Psikologi ${ }^{2)}$ \\ Universitas Islam Indonesia, Jl Kaliurang Km 14, Yogyakarta, Indonesia \\ Email:nnur@uii.ac.id
}

\begin{abstract}
ABSTRAK
Teknologi digital mudah diadopsi oleh kalangan muda, sehingga pembelajaran teknologi bisa dilakukan secara formal, informal maupun nonformal seperti di sekolahrumah (homeschooling). Meskipun demikian, sebagian komunitas sekolahrumah menghadapi beberapa keterbatasan, antara lain kompetensi pengajar, tingkat literasi digital siswi, dan ketersediaan fasilitas teknologi digital yang belum optimal. Guna meningkatkan kompetensi di sekolahrumah komunitas setingkat SMP, yaitu sekolahrumah Salihah Yogyakarta, telah diadakan rangkaian kegiatan pelatihan pemanfaatan Teknologi Informasi (TI) bagi para guru dan siswi. Kegiatan tersebut berupa sosialisasi kepada guru dan orang tua, penyusunan materi pelatihan, pelatihan bagi para guru mengenai komputer modern, pelatihan literasi digital berupa konten multimedia bagi siswi dan orang tua, serta evaluasi kegiatan terhadap siswi selama pelaksanaan dan sesudah pelatihan. Pelatihan multimedia kepada siswi berisi pelatihan animasi, poster digital, video, dan gim dengan tema pandemi Covid-2019. Evaluasi dari hasil survei menunjukkan bahwa separuh siswi merasa senang dengan kegiatan pelatihan. Dua materi favorit adalah pembuatan animasi dan poster digital, sedangkan materi pelatihan gim dan video dianggap sulit. Selain itu, sebagian orang tua merasa senang dengan adanya pelatihan multimedia ini, meskipun ada juga orang tua yang kesulitan mendampingi para siswi karena orang tua merasa kurang menguasai teknologi. Hal ini menunjukkan bahwa perlu ada upaya untuk menumbuhkan persepsi positif mengenai kemudahan menggunakan TI. Tindak lanjut lainnya adalah pendampingan berkelanjutan untuk meningkatkan literasi digital para siswi dan orang tua sekolahrumah Salihah Yogyakarta.
\end{abstract}

Kata kunci: pelatihan animasi, pelatihan literasi digital, pelatihan multimedia, sekolahrumah Salihah Yogyakarta, siswa SMP

\begin{abstract}
Young people could learn and use technology in formal, informal and nonformal education effortlessly. As a legal nonformal education, homeschooling programs become more popular because the programs demonstrate some advantages, such as customized learning materials, personalized learning methods, and flexible learning schedules. However, some homeschooling communities face several problems related to digital literacy skill because of lack of teachers' capacity and tools. To support digital literacy, a series of training has been conducted for teachers and students at Salihah Homeschool, Yogyakarta. It consisted of training of modern computer technology for teachers and multimedia training for students and parents. The second training taught students on how to make digital posters, videos, animations, and games related to Covid-19 pandemic. Survey showed half of the students were happy with the training activities. Furthermore, the most preferred lessons were animation and digital posters, while game and video tutorials were perceived difficult. Nevertheless, student participation showed a declining trend since the second day of training. Moreover, some parents expressed happiness with the training contents, but there were also parents who found difficulty as the parents were novice users. It implies future efforts to promote positive awareness of the ease of using IT and continuous monitoring to improve digital literacy.
\end{abstract}

Keywords: animation training, digital literacy, multimedia training, nonformal education, Salihah homeschooling of Yogyakarta 


\section{Pendahuluan}

Pemilihan lembaga pendidikan yang tepat bagi anak, merupakan salah satu faktor penentu keberhasilan pendidikan. Selain pendidikan formal, Pemerintah Indonesia telah membuka peluang dan melegitimasi kesetaraan ijazah Paket A, Paket B dan Paket C (yang dikeluarkan oleh satuan pendidikan informal/nonformal) dengan ijazah SD/MI, SMP/MTs dan SMA/MA/SMK (KemdikbudRI, 2014). Di Yogyakarta, sejumlah 93 murid Paket A, 230 murid Paket B dan 440 murid Paket C telah mengikuti Ujian Nasional untuk Kesetaraan (UNPK) berbasis komputer pada tahun 2018.

Satuan pendidikan berupa sekolahrumah (homeschooling) merupakan salah satu bentuk pendidikan nonformal yang kini makin dipertimbangkan oleh orang tua. Sekolahrumah bisa berbentuk tunggal (terdiri dari satu keluarga), majemuk (gabungan beberapa keluarga), hingga komunitas (gabungan dari sekolahrumah majemuk).

Sekolahrumah majemuk Salihah, Yogyakarta, didirikan pada tahun 2018 dengan tujuan mendidik anak-anak perempuan setingkat SMP dan diposisikan sebagai lembaga pendidikan nonasrama yang berbasis agama Islam. Fleksibilitas materi belajar, metode pembelajaran, dan jadwal belajar menjadi salah satu kelebihan sekolahrumah. Karena baru berdiri, sekolahrumah Salihah memiliki beberapa keterbatasan dalam hal kompetensi Sumber Daya Manusia (SDM) para guru dan sarana dan prasarana, termasuk dalam bidang Teknologi Informasi (TI). Beberapa guru mengeluhkan sulitnya mengatasi beberapa siswa yang sangat aktif. Sebagian siswa tampak mudah bosan dan kadang-kadang tidak memperhatikan penjelasan guru. Kondisi ini semakin sulit karena sebagian besar guru belum banyak berpengalaman dalam mengajar.

Berdasarkan permasalahan sekolahrumah Salihah di atas, kegiatan pengabdian masyarakat ini dilakukan dengan tujuan untuk meningkatkan kompetensi para guru dan siswi sekolahrumah Salihah, dengan memberikan pelatihan belajar multimedia dengan harapan mampu meningkatkan literasi digital bagi guru, siswi dan orang tua. Literasi digital dalam pengabdian masyarakat ini difokuskan pada pembelajaran animasi, poster, video, dan gim agar ada inovasi dalam metode atau proses belajar mengajar, dan kegiatan belajar akan menjadi lebih menyenangkan. Pelatihan kepada orang tua juga dilakukan agar orang tua memiliki keterlibatan dalam pembelajaran siswa di rumah.

\section{Tinjauan Pustaka}

\subsection{Sekolahrumah}

Sekolahrumah (homeschooling) adalah proses layanan pendidikan yang secara sadar dan terencana dilakukan oleh orangtua/keluarga di rumah atau tempat-tempat lain dalam bentuk tunggal, majemuk, dan komunitas dimana proses pembelajaran dapat berlangsung dalam suasana yang kondusif dengan tujuan agar setiap potensi peserta didik yang unik dapat berkembang secara maksimal (Kemdikbud-RI, 2014).

Terdapat 3 jenis sekolahrumah sesuai dengan peraturan Mendikbud nomor 129 tahun 2014, yaitu:

1. Sekolahrumah tunggal: proses pendidikan sekolahrumah yang dilakukan sendiri oleh orang tua kepada anaknya, baik tanpa atau dengan bantuan guru les secara mandiri.

2. Sekolahrumah majemuk: terdiri dari 2 atau lebih keluarga sekolahrumah tunggal yang menyelenggarakan pembelajaran bersama.

3. Sekolahrumah komunitas: terdiri dari gabungan sekolahrumah majemuk yang menyelenggarakan pembelajaran bersama.

\subsection{Literasi Digital}

Sejumlah istilah telah dipakai secara luas untuk menilai kompetensi dan ketrampilan dalam menggunakan teknologi digital, antara lain ketrampilan Teknologi Informasi dan Komunikasi (TIK), ketrampilan teknologi, ketrampilan teknologi informasi, ketrampilan abad ke-21, ketrampilan internet, literasi informasi, ketrampilan digital, literasi digital, dan kompetensi digital (Ilomäki et al., 
2011). Meskipun sebagian peneliti membedakan antara literasi digital dan kompetensi digital (AlaMutka, 2011; Spante et al., 2018), akan tetapi sejumlah literatur menyebutkan bahwa kedua istilah tersebut dapat dipertukarkan (Godhe, 2019; Ilomäki et al., 2011). Istilah-istilah tersebut dipakai dalam beragam ruang lingkup teknis dan kondisi sosial, serta tercantum dalam dokumen-dokumen resmi (antara lain artikel penelitian dan dokumen kurikulum). Misalnya, istilah kompetensi digital (digital competence) banyak dipakai dalam penelitian-penelitian di negara Eropa dan Amerika Selatan, sedangkan istilah literasi digital (digital literacy) lebih banyak digunakan di Asia (Spante et al., 2018), termasuk Indonesia.

Kementerian Pendidikan dan Kebudayaan RI telah menerbitkan panduan gerakan literasi nasional yang menyebutkan bahwa pemerintah menggalakkan 6 budaya literasi nasional, yaitu literasi baca tulis, literasi numerasi, literasi sains, literasi digital, literasi finansial, dan literasi kewargaan (Kemdikbud-RI, 2017). Keenam literasi tersebut perlu ditumbuhkan di tingkat keluarga, sekolah dan masyarakat, misalnya dengan meningkatkan peran ibu sebagai pendidik informal di rumah (Rahayu \& Haningsih, 2021). Langkah-langkah tersebut perlu dilakukan karena teknologi dapat digunakan anak dalam rangka berbagi informasi/belajar, berkomunikasi/berpartisipasi atau untuk hiburan (Duerager \& Livingstone, 2012; Rodríguez-de-Dios et al., 2018; Tennakoon et al., 2018).

\subsection{Uji Coba Pemanfaatan Teknologi}

TI telah menjadi kebutuhan sehari-hari, meskipun tidak semua orang menguasai TI karena faktor usia atau faktor eksternal lain (Barnard et al., 2013). Oleh karena itu, beragam studi telah membahas upaya uji coba inovasi (trialability), termasuk dalam bidang Teknologi Informasi (TI). Misalnya, trialability menjadi komponen perbandingan kriteria pembelajaran (Panigrahi et al., 2018) dan sebagai parameter keberhasilan pemanfaatan TI bagi pelaku Usaha Kecil dan Menengah (Tan et al., 2009), penduduk desa (Eder et al., 2015; Helitzer et al., 2003; Ramavhona \& Mokwena, 2016) serta orang lanjut usia (Barnard et al., 2013).

Penelitian menunjukkan bahwa semakin banyak inovasi yang diuji coba, maka adopsi TI juga menjadi semakin cepat (Diana et al., 2020). Hal ini telah ditunjukkan dalam sebuah penelitian terhadap aplikasi pembelajaran oleh pemakai TI usia muda (siswa sekolah) berdasarkan kepemilikan piranti teknologi, akses aplikasi, dan persepsi kemampuan pengoperasian siswa (Diana et al., 2020). Hasil tersebut juga diperkuat oleh studi Wachiuri yang menyarankan adanya tahapan trialability sebelum pihak sekolah membeli peralatan TI (Wachiuri, 2015).

\subsection{Pelatihan Literasi Digital Bagi Siswa SMP}

Beragam kegiatan komunitas, buku dan aktivitas literasi digital telah dilaksanakan di Indonesia. Penelitian menunjukkan bahwa sejumlah 342 kegiatan literasi digital telah berlangsung selama 20102017. Kegiatan-kegiatan tersebut berupa ceramah/sosialisasi, workshop/pelatihan, seminar/ diskusi, penelitian, dan talkshow (Kurnia \& Astuti, 2017). Sedangkan kelompok sasaran kegiatan adalah remaja/pelajar usia sekolah (29.6\%), mahasiswa (18.6\%) dan masyarakat umum (15.2\%).

Beragam pelatihan di tingkat SMP telah dilaksanakan dalam studi-studi sebelumnya, mulai dari pelatihan tanpa TI (Nur et al., 2020; Ratnaya et al., 2017) hingga pelatihan dengan memanfaatkan TI. Sasaran pelatihan juga beragam, baik kepada guru (Hartanto \& Nurharjanti, 2018) maupun bagi siswa. Contoh pelatihan bagi para siswa SMP antara lain pelatihan penelusuran informasi elektronik dan penulisan karya ilmiah (Agustina et al., 2019) dan konten edukatif dalam format video (Khotimah et al., 2020). Studi-studi tersebut menunjukkan hasil positif, antara lain peningkatan kemampuan para siswa dalam mencari sumber informasi secara elektronik, kemampuan mengutip dan menuliskan daftar pustaka, kemampuan menyusun karya ilmiah secara berkelompok, bersikap lebih berhati-hati dalam memanfaatkan media sosial serta kemampuan dalam menggunakan media sosial sebagai media penunjang kegiatan belajar. 


\section{Metodologi Pengabdian Masyarakat}

Rangkaian kegiatan pelatihan ini dilaksanakan di sekolahrumah Salihah yang berlokasi di daerah Ambarrukmo, Kecamatan Depok, Kabupaten Sleman, D.I. Yogyakarta. Guna mendidik para siswi agar mendapat bekal agama yang baik, sekolahrumah Salihah mempunyai 4 program unggulan, yaitu tahsin (perbaikan) dan tahfidz (hafalan) Al-Quran, bahasa Arab, dan pengembangan diri (Salihah, 2018). Pengembangan diri terdiri dari berbagai keahlian, antara lain keputrian dan teknologi informasi.

Secara detail, kegiatan pengabdian masyarakat ini berlangsung selama Januari - April 2020 dengan tahapan pelaksanaan sebagai berikut:

1. Sosialisasi kepada guru dan orang tua. Sosialisasi kepada para guru dilaksanakan pada acara pembekalan guru, sedangkan sosialisasi kepada orang tua diberikan pada pekan perdana kegiatan belajar mengajar.

2. Penyusunan materi pelatihan, yaitu materi pengenalan komputer modern (bagi guru) dan pemanfaatan aplikasi bagi para siswi agar dapat membuat produk multimedia. Para siswi diajari untuk belajar membuat poster digital, video, animasi dan gim di gawai berbasis Android.

3. Pelatihan bagi para guru dalam bentuk ceramah mengenai eksistensi komputer dalam era modern.

4. Uji coba pemanfaatan teknologi berupa pelatihan bagi siswi dan orang tua mengenai cara membuat poster digital, video, animasi dan gim dengan tema pandemi Covid-2019. Pelatihan bagi siswi yang berlangsung di masa pandemi Covid-19 ini dikelola sedemikian rupa sehingga para siswi juga belajar di rumah didampingi oleh orang tua/wali masing-masing. Oleh karena tidak semua siswi memiliki komputer, pelatihan difokuskan pada penggunaan gawai/ponsel pintar.

5. Evaluasi kegiatan terhadap siswi selama pelaksanaan dan sesudah pelatihan, yaitu berupa observasi terhadap minat siswi. Evaluasi pasca pelatihan dilakukan dengan kuesioner mengenai pengalaman, tingkat kesulitan, dan masukan untuk pemateri.

Secara ringkas, gambaran teknis pelatihan ditunjukkan di Gambar 1.

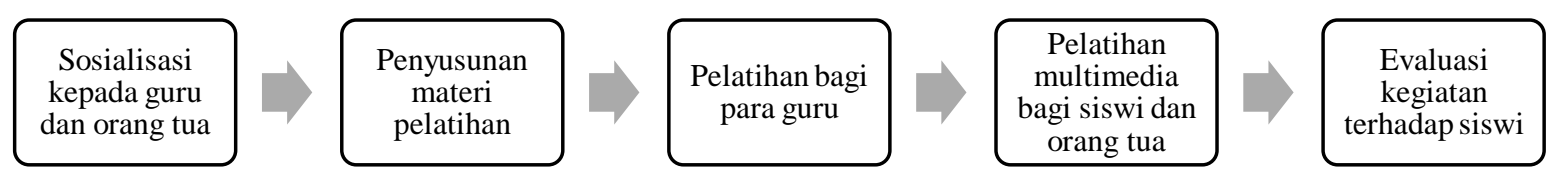

Gambar 1. Diagram Blok Pelaksanaan Seluruh Kegiatan

\section{Hasil Dan Pembahasan}

Pelaksanaan setiap rencana aktivitas pengabdian masyarakat ke sekolahrumah Salihah adalah sebagai berikut:

1. Sosialisasi kepada guru dan orang tua

Sosialisasi kepada para guru dan orang tua berjalan lancar. Para guru yang relatif masih muda memiliki kemampuan dasar terkait teknologi dan bersemangat untuk belajar mengenai komputer dan internet. Orang tua juga antusias dengan rencana untuk melaksanakan beragam kegiatan pengembangan diri, antara lain memasak, pengenalan usaha, TI dan kerajinan tangan.

2. Penyusunan materi pelatihan

Materi pelatihan terdiri dari 2 bagian, yaitu pengenalan komputer modern (bagi guru) dan pemanfaatan aplikasi bagi para siswi agar dapat membuat produk multimedia. Para siswi diajari untuk belajar membuat poster digital, video, animasi dan gim di gawai berbasis Android. Tutorial diberikan dalam bentuk video yang terunggah di YouTube di kanal sekolahrumah Salihah yang terdiri dari: 
a) Tutorial poster digital dengan menggunakan Canva yang terdiri dari 4 video tutorial, yaitu: (i) unduh \& masuk ke Canva, (ii) membuat poster dari template yang tersedia, (iii) membuat poster bukan dari template (tingkat dasar) dan (iv) membuat poster bukan dari template (tingkat lanjut).

b) Tutorial video digital dengan menggunakan aplikasi Cinema FV-5 Lite dan Beecut. Video tutorial terbagi menjadi 3 bagian, yaitu: (i) video kreatif dengan ponsel pintar, (ii) tips kreatif menyunting cerita, dan (iii) cara apik mempublikasikan karya.

c) Tutorial animasi dengan bantuan aplikasi Flipaclip yang berupa 4 video tutorial, yaitu: (i) membuat proyek baru, (ii) pengenalan kakas (tool), (iii) membuat animasi virus loncat, serta (iv) menambah suara, teks, dan mengekspor file.

d) Tutorial gim dengan MIT AppInventor yang terdiri dari 2 bagian, yaitu: (i) pembuatan layout, komponen gim, dan blocks programming, serta (ii) desain halaman permainan, logika pemrograman, dan blok permainan.

3. Pelatihan bagi para guru

Pelatihan bagi para guru dilakukan dalam bentuk ceramah mengenai eksistensi komputer dalam era modern. Inti materi ceramah berisi informasi cara kerja komputer/internet dan pengetahuan bahwa komputer yang tidak hanya berbentuk PC atau laptop. Semua guru hadir dalam pelatihan tersebut, ditambah dengan 1 guru dari TK Imam Syafi'i, sebuah institusi pendidikan yang berlokasi dekat sekolahrumah Salihah.

4. Uji coba pemanfaatan teknologi (pelatihan multimedia)

Pelatihan multimedia bagi siswi yang berlangsung selama 4 hari dengan cara membagi satu materi untuk setiap hari. Oleh karena pelatihan dilaksanakan di rumah, komunikasi yang lancar merupakan salah satu faktor penting agar pelatihan dapat berhasil. Terdapat 2 alat bantu komunikasi yang dipakai, yaitu aplikasi Whatsapp (pribadi dan grup) untuk berbagi pengumuman atau sarana pengiriman hasil penugasan, serta Google Drive sebagai wadah pengumpulan tugas. Adapun alur komunikasi yang berlangsung selama pelatihan ditunjukkan di Gambar 2.

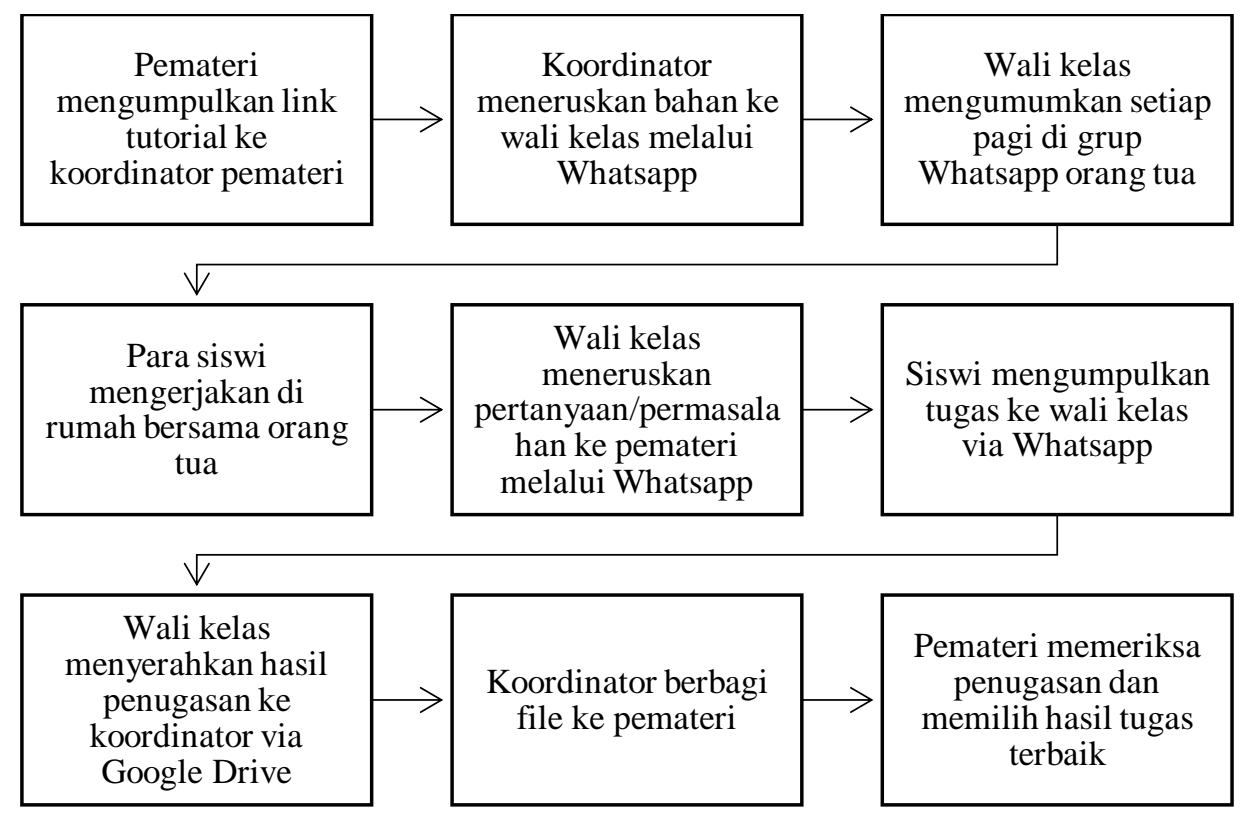

Gambar 2. Diagram Alir Pelatihan Multimedia Di Rumah 
Sejumlah 14 dari 15 siswi (93,3\%) mengikuti dan mengumpulkan tugas pelatihan multimedia, dengan dinamika pengumpulan per tugas yang menunjukkan tren penurunan (Gambar 3), mulai dari hari ke-1 pelatihan (materi poster), hari ke-2 (materi video), hari ke-3 (animasi) hingga hari terakhir (materi gim). Menurunnya jumlah siswi yang mengikuti pelatihan berkorelasi dengan naiknya tingkat kesulitan yang dirasakan mereka. Hal ini dapat disebabkan oleh adanya proses maturasi pada siswi yaitu makin lelah atau merasa makin sulit. Dalam penelitian-penelitian eksperimen atau dalam hal ini ialah pelatihan, fenomena berkurangnya subjek yang mengikuti pelatihan adalah wajar dan menjadi permasalahan yang lazim selama tidak mempengaruhi validitas internal.

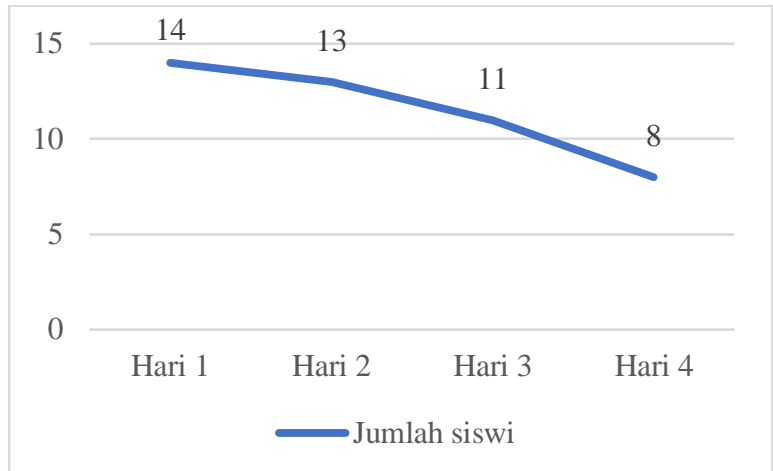

Gambar 3. Dinamika Jumlah Siswi Mengikuti Pelatihan

5. Evaluasi kegiatan terhadap siswi

Evaluasi yang dilakukan setiap hari oleh wali kelas menunjukkan bahwa para siswi justru merasakan peningkatan kesulitan seiring dengan bertambahnya hari. Masalah yang muncul umumnya berupa kesulitan teknis dalam pengoperasian, misalnya gagal mengunduh aplikasi (disebabkan lupa password akun Gmail), kesulitan mengunduh file pendukung (karena ketidaktelitian dalam membaca seluruh instruksi), serta kesulitan dalam mengoperasikan aplikasi MIT AppInventor (materi gim). Kesulitan-kesulitan teknis tersebut telah diupayakan diatasi oleh wali kelas dengan cara mengomunikasikannya dengan para pemateri.

Selain kesulitan teknis, terdapat 3 macam kesulitan lain yang dialami oleh para siswi, yaitu kesulitan dalam memahami penjelasan/materi, kesulitan dalam mengalokasikan waktu karena waktu untuk mengerjakan praktek ternyata lebih lama daripada yang diperkirakan, hingga kesulitan siswi dalam mencoba sesuatu yang baru (lihat sebaran di Gambar 4). Seperti yang diungkapkan oleh salah seorang siswi, "Ada yang mudah namun ada juga yang sulit, terkadang yang lebih susah paham namun setelah dicoba justru lebih mudah tapi ada juga yang mana saat dijelaskan sudah paham tapi saat mencoba justru malah sulit”.

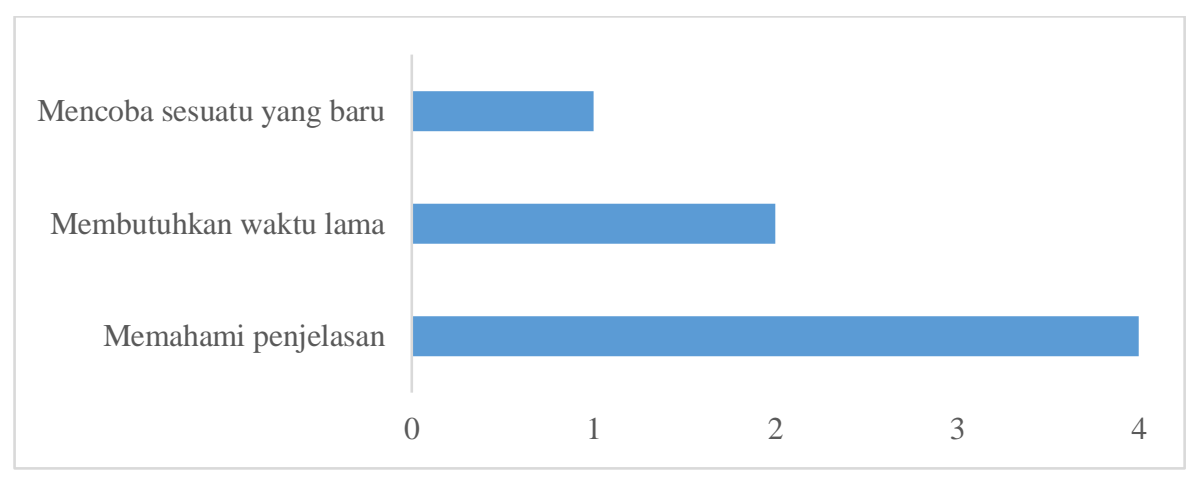

Gambar 4. Ragam Kesulitan Non Teknis Pengoperasian 
Secara kuantitatif, tingkat minat siswi ditunjukkan dengan angka partisipasi dalam penugasan. Dengan demikian, terdapat penilaian "Sangat berminat" untuk siswi yang mengerjakan semua tugas dari 4 materi, "Berminat" untuk siswi yang mengerjakan 3 tugas, "Kurang berminat" untuk siswa yang hanya mengerjakan 1-2 tugas, dan "Tidak berminat" untuk siswi yang tidak mengerjakan sama sekali. Rekapitulasi minat siswi yang terdapat di Gambar 5 menunjukkan bahwa mayoritas siswi $(86 \%)$ berminat atau sangat berminat.

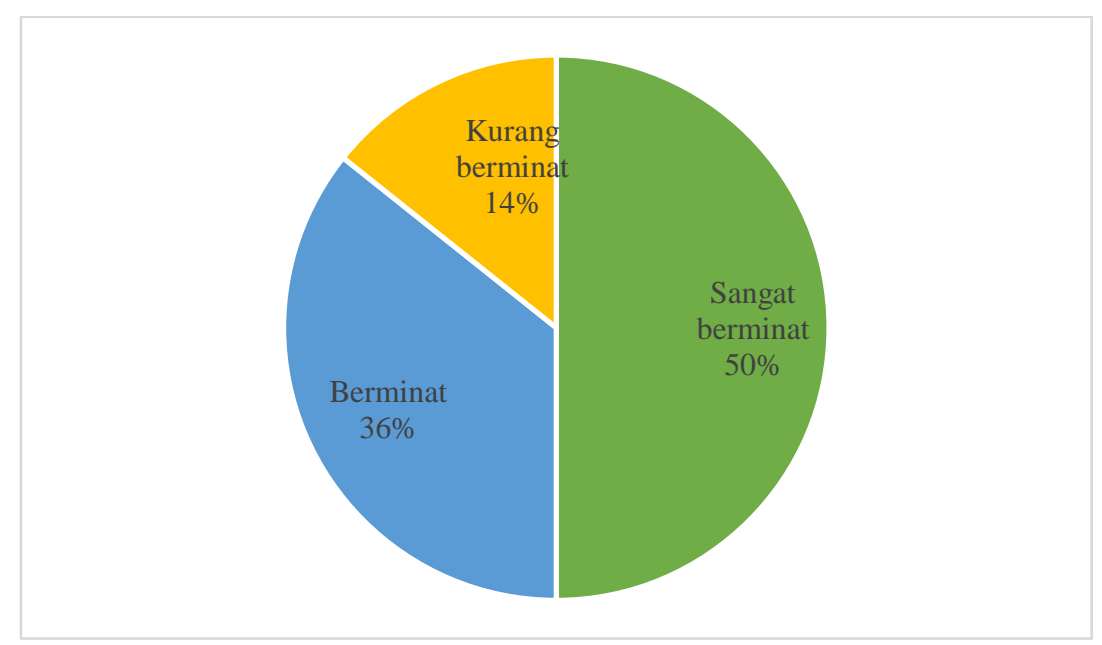

Gambar 5. Minat Siswi Terhadap Pelatihan

Evaluasi dari hasil survei menunjukkan bahwa separuh siswi merasa senang dengan kegiatan pelatihan tersebut, meskipun ada beberapa kesulitan yang dijumpai. Hal ini dikarenakan para siswi menganggapnya sebagai pengalaman baru yang unik dan luar biasa, seperti yang dijelaskan pada penelitian sebelumnya (Barnard et al., 2013). Terdapat 2 materi yang dianggap sangat sulit, yaitu gim dan video, sedangkan materi yang paling disukai adalah membuat animasi dan poster (contoh hasil penugasan siswi ditunjukkan di Gambar 6).

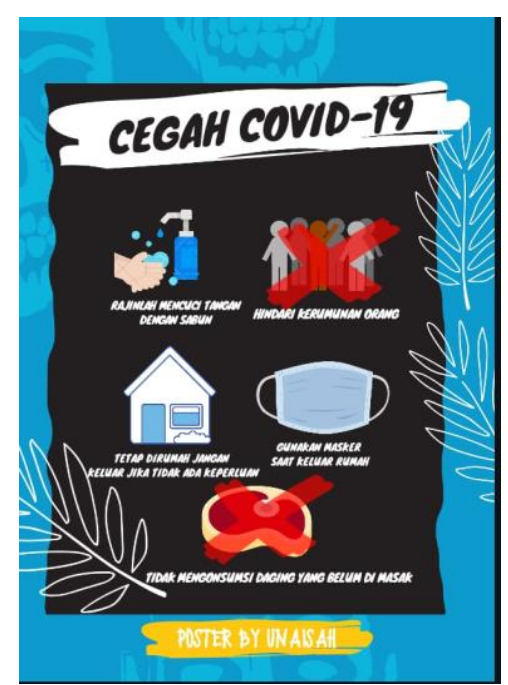

(a)

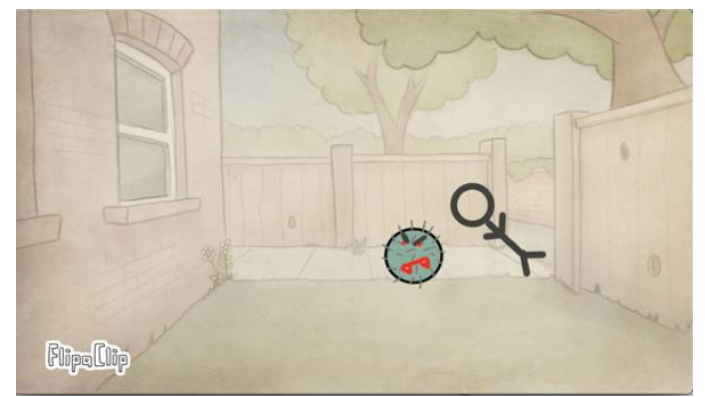

(b)

Gambar 6. Contoh Hasil Penugasan (a) Poster dan (b) Animasi

Evaluasi yang dilakukan kepada para orang tua juga menunjukkan hal yang mirip, mulai dari orang tua yang senang hingga orang tua yang merasa kesulitan. Kesulitan ini terutama 
dikarenakan orang tua merasa kurang menguasai materi yang dilatihkan sehingga tidak mampu membantu anaknya.

\section{Kesimpulan}

Pengetahuan mengenai komputer era modern telah diberikan kepada para guru sekolahrumah Salihah Yogyakarta dan uji coba pembuatan multimedia digital juga telah dipraktikkan 14 siswinya. Kesimpulan dan saran dari rangkaian pelaksanaan kegiatan ini adalah sebagai berikut:

1. Hasil evaluasi menunjukkan bahwa $86 \%$ siswi berminat dalam pelatihan literasi digital. Hal ini ditunjukkan dengan jumlah kehadiran dan penugasan yang telah dikerjakan oleh para siswi.

2. Sebagian siswi mengaku merasa kesulitan, baik dalam hal teknis maupun non teknis. Contoh kesulitan yang dihadapi adalah kesulitan memahami penjelasan/materi, kesulitan dalam mengalokasikan waktu yang lebih lama dari ekspektasi, serta kesulitan dalam mencoba sesuatu yang baru. Kesulitan-kesulitan tersebut juga tercermin pada frekuensi kehadiran yang menurun. Oleh karena itu, rekomendasi terhadap masalah ini adalah dengan cara mengurangi jam pelatihan atau mendesain kembali pelatihan yang lebih efektif dan efisien.

3. Respons para orang tua bervariasi, mulai dari senang hingga merasa kesulitan dalam mendampingi anak-anaknya mengerjakan tugas pelatihan.

4. Pemanfaatan gawai berupa ponsel pintar dalam beberapa materi pelatihan memiliki beberapa kekurangan, antara lain layar yang kecil (sehingga tombol-tombol di aplikasi sulit dioperasikan) dan tingginya frekuensi penggunaan. Masalah tersebut dapat diatasi dengan memanfaatkan komputer di rumah atau menggunakan komputer sekolah apabila kelak sekolahrumah Salihah telah memiliki laboratorium komputer sendiri.

Implikasi dari kegiatan ini menunjukkan bahwa perlu ada upaya untuk menumbuhkan persepsi positif para orang tua dan siswi mengenai kemudahan menggunakan TI. Selain itu, diperlukan pendampingan berkelanjutan untuk meningkatkan literasi digital para siswi yang disesuaikan dengan kemampuan masing-masing siswi.

\section{Acknowledgement}

Tim pengabdi menyampaikan terima kasih dan apresiasi kepada Direktorat Penelitian dan Pengabdian Masyarakat UII yang telah memberikan hibah Pengabdian Unggulan.

\section{Daftar Pustaka}

Agustina, R., S., Pramesti, U. D., \& Rasyid, Y. (2019). Pelatihan Penelusuran Informasi Elektronik dalam Peningkatkan Keterampilan Menulis Karya Ilmiah Siswa SMPN. JP-IPTEKS: Jurnal Pengabdian Kepada Masyarakat, 65-74.

Ala-Mutka, K. (2011). Mapping Digital Competence: Towards a Conceptual Understanding. ftp://jrc.es/pub/EURdoc/JRC67075_TN.pdf

Barnard, Y., Bradley, M. D., Hodgson, F., \& Lloyd, A. D. (2013). Learning to use new technologies by older adults: Perceived difficulties, experimentation behaviour and usability. Computers in Human Behavior, 29(4), 1715-1724. https://doi.org/10.1016/j.chb.2013.02.006

Diana, L., Hadining, A. F., \& Fitriani, R. (2020). Analisis Faktor yang Mempengaruhi Adopsi Rumah Belajar di Kabupaten Karawang. MTI: Jurnal Penelitian Teknologi Informasi Dan Komunikasi, 11(2), 79. https://doi.org/10.17933/mti.v11i2.180

Duerager, A., \& Livingstone, S. (2012). How can parents support children's internet safety? In $E U$ Kids Online. http://eprints.lse.ac.uk/42872/1/How can parents support children's internet safety(lsero).pdf

Eder, J. M., Mutsaerts, C. F., \& Sriwannawit, P. (2015). Mini-grids and renewable energy in rural Africa : How diffusion theory explains adoption of electricity in Uganda. Energy Research \& 
Social Science, Special Issue on Renewable Energy in Sub-Saharan Africa: Contributions from the Social Sciences, 5, 45-54.

Godhe, A.-L. (2019). Digital Literacies or Digital Competence: Conceptualizations in Nordic Curricula. Media and Communication, 7(2), 25-35. https://doi.org/10.17645/mac.v7i2.1888

Hartanto, A. D., \& Nurharjanti, M. (2018). Implementasi teknologi pembelajaran dan kelas digital untuk SMP kota Yogyakarta. Prosiding Seminar Nasional Seri 8 "Mewujudkan Masyarakat Madani Dan Lestari," September, 58-65.

Helitzer, D., Sc, D., Heath, D., Maltrud, K., Sullivan, E., \& Alverson, D. (2003). Assessing or Predicting Adoption of Telehealth Using the Diffusion of Innovations Theory: A Practical Example from a Rural Program in New Mexico. 9(2).

Ilomäki, L., Kantosalo, A., \& Lakkala, M. (2011). What is digital competence? https://pdfs.semanticscholar.org/1aec/5078d57d4d9d70e6d34a7603cf8609579bea.pdf

Kemdikbud-RI. (2014). Peraturan Mendikbud No 129 Tahun 2014 tentang Sekolahrumah. https://jdih.kemdikbud.go.id/arsip/Permendikbud Nomor 129 Tahun 2014.pdf

Kemdikbud-RI. (2017). Panduan Gerakan Literasi https://gln.kemdikbud.go.id/glnsite/wp-content/uploads/2017/08/panduan-gln.pdf

Khotimah, W. Q., Agustini, V. D., \& Supriyadi, A. (2020). Pelatihan Membuat Konten Edukatif untuk Media Sosial bagi Siswa SMP Muhammadiyah 4 Cipondoh Tangerang di Masa Pandemi Covid-19. Journal of Servite, 2(2), 49. https://doi.org/10.37535/102002220205

Kurnia, N., \& Astuti, S. I. (2017). Peta Gerakan Literasi Digital di Indonesia: Studi tentang Pelaku, Ragam Kegiatan, Kelompok Sasaran dan Mitra. Informasi, 47(2), 149-166.

Nur, A. M., Mubarok, Y., Washadi, \& Risnawati, E. (2020). Pelatihan Penulisan Cerpen Remaja pada Siswa SMP Negeri 8 Kota Tangerang Selatan. JURNAL CEMERLANG: Pengabdian Pada Masyarakat, 2(2), 148-161. https://doi.org/10.31540/jpm.v2i2.910

Panigrahi, R., Srivastava, P. R., \& Sharma, D. (2018). Online learning : Adoption, continuance, and learning outcome - A review of literature. International Journal of Information Management, 43(May), 1-14. https://doi.org/10.1016/j.ijinfomgt.2018.05.005

Rahayu, N. W., \& Haningsih, S. (2021). Digital parenting competence of mother as informal educator is not inline with internet access. International Journal of Child-Computer Interaction. https://doi.org/10.1016/j.ijcci.2021.100291

Ramavhona, T. C., \& Mokwena, S. (2016). Factors influencing Internet banking adoption in South African rural areas. South African Journal of Information Management, 18(2), 1-8.

Ratnaya, I. G., Santiyadnya, N., Krisnawari, L., Nurhayata, I. G., Sudaryana, I. G. S., \& Wahyuni, N. M. (2017). Pelatihan Fotografi Untuk SMP, SMA, dan SMK di Kota Singaraja. Seminar Nasional Vokasi Dan Teknologi (SEMNASVOKTEK), 380-384.

Rodríguez-de-Dios, I., Oosten, J. M. F. van, \& Igartua, J.-J. (2018). A study of the relationship between parental mediation and adolescents ' digital skills, online risks and online opportunities. Computers in Human Behavior, 82, 186-198. https://doi.org/10.1016/j.chb.2018.01.012

Salihah, S. (2018). Website Resmi Sekolah Salihah. https://www.sekolahsalihah.org/kurikulum/program-unggulan/

Spante, M., Hashemi, S. S., Lundin, M., \& Algers, A. (2018). Digital competence and digital literacy in higher education research: Systematic review of concept use. Cogent Education, 5, 1-21. https://doi.org/10.1080/2331186X.2018.1519143

Tan, K. S., Chong, S. C., Lin, B., \& Eze, U. C. (2009). Internet-based ICT adoption : Evidence from Malaysian SMEs. Industrial Management \& Data Systems, 109(2), 224-244. https://doi.org/10.1108/02635570910930118

Tennakoon, H., Saridakis, G., \& Mohammed, A.-M. (2018). Child online safety and parental intervention: a study of Sri Lankan internet users. Information Technology \& People, 31(3), 770-790. https://doi.org/10.1108/ITP-09-2016-0213 
Wachiuri, R. N. (2015). Trialability of Assistive Technology in the Teaching and Learning of Integrated English Among the Visually Impaired Learners in Special Secondary Schools in Kenya. International Journal of Advanced Research in Education Technology, 2(3). https://doi.org/10.17265/2161-623x/2017.01.003 